Working Paper 8601.

\title{
EMPLOYMENT AND UNEMPLOYMENT EFFECTS OF UNIONS
}

By Edward Montgomery

Edward Montgomery is an assistant Professor of Economics. School of Urban and Public Affairs, Carnegie-Mellon University. Financial assistance for this study was provided by the Federal Reserve Bank of Cleveland. Thanks to Ralph Day for excellent research assistance and to Carole McCoy for typing the manuscript.

Working Papers of the Federal Reserve Bank of Cleveland are preliminary materials, circulated to stimulate discussion and critical comment. The views stated herein are the author's and not necessarily those of the Federal Reserve Bank of Cleveland or of the Board of Governors of the Federal Reserve System.

January 1986 


\section{Introduction}

There is a large body of empirical literature that suggests that unions can and do raise the relative wages of their members.' In addition, unions have been found to affect the wages of non-union members. although the direction and magnitude of this effect is somewhat more ambiguous. Despite an extensive literature that examines the effect of unions on wages, little attention has been paid to the resultant employment consequences of this change in the relative cost of unionized labor. The purpose of this study is to examine the effect of unions on the aggegate level of employment in the economy. In section II of this paper, previous efforts to examine this question are discussed, while in section III, a theoretical model of the effect of unions on employment and unemployment is developed and analyzed. In section IV, this framework is used to derive and estimate employment and labor force participation equations. The empirical analysis differs from previous efforts, in part. because it explicitly captures the effect of both the proportion unionized and the size of the union wage premium on various measures of employment. In particular, these regressions provide estimates of the effect of differences in union strength across standard metropolitan statistical area (SMSAS) on the likelihood that an individual will be employed, in the labor force, or unemployed. By examining the effect of unions on the size of the labor force and on the total number of employed,

1. See Parsley (1980) for a review of this voluminous literature. 
this study also differs from much of the previous work that has concentrated solely on the effect of unions on the relative number of union and non-union workers. Finally, by examining whether differences in the extent of union power across labor markets alter the mix of part-time and full-time jobs. this study can also analyze the effect of unionism on the workweek.

An analysis of the employment effects of unionism can play a role in assessing the welfare implications of changes in the extent of unionization in the economy. The potentially deleterious effect of unions on employment is also of importance to those interested in regional unemployment differences. A recent study by Murphy (1985) found that differences in the sensitivity to demand conditions in the product market and wage differentials are vital in determining regional differences in unemployment rates. Since unions have been found to affect both of these variables. differences in the extent or impact of unionism may be important in understanding regional unemployment rate differentials. In fact, Freeman and Medoff (1984) have presented evidence that suggests that unemployment rates are 1.0 percent higher in areas with a high degree of unionism relative to low unionism areas. However, since they also fail to find any correlation between the degree of unionism and the employment rate, a further. more explicit analysis of this question seems to be necessary to determine what effect, if any, unions have on aggregate and regional employment rates. 


\section{Previous Literature}

Despite the rather extensive attention paid to the effect of unions on relative wages, there has been scant attention paid to the attendant employment consequences.' Most of the studies done on the employment effects of unions have been on the industry level.' Industry or firm studies, however. may overestimate the disemployment effect of unions, because they ignore the fact that some or all of the displaced workers may become employed again in other industries or firms. Consequently, these studies cannot provide estimates of the net or aggregate employment effect of unions.

Lewis (1963 and 1964) provided the first analysis of the relative wage and, employment effects of unions on an aggregate basis. In these papers, Lewis divides the economy into a union and a non-union sector. Industries with a relatively high degree of unionism, like manufacturing and mining, were grouped into the unionized sector. while those with a low degree of unionism were grouped into a non-union sector." Using time series data, he estimates whether changes in relative employment levels across these two sectors can be attributed to differences in the average union/non-union wages premium and the average percent unionized. His results suggest that unions

2. There have been studies of the relative wage effect of unions across industries, occupations, and race and gender groups.

3. See Lewis (1963) for a review of some of these industry studies.

4. The union sector was made up of mining, construction, manufacturing, transportation, and communication and public utilities. The non-union sector was made up of all others, except military and government relief. 
have a significant negative effect on relative employment levels and manhours worked.

Pencavel and Hartsog (1984) recently updated and extended this seminal work. However, they failed to find any consistently negative impact of unionism on manhours. In fact, they conclude that the hypothesis that unionism depresses manhours can be accepted only for the late 1920s and early 1930s. This basic result is not sensitive to whether the employment and wage effects of unions are estimated with Lewis's reduced form model or with a structural model that they developed."

The ambiguity of these results may be due aggregate data not being well-suited to testing the employment effects of unionism.' Aggregating industries into two sectors, as was done in these studies, ignores the effects of unions within these sectors, and thus may not yield good estimates of the overall effect of unions on employment and wages. Further, the absence of controls for changes in labor quality across sectors means that these studies might overestimate the impact of unions on wages and underestimate the effects on employment. That is, if firms respond to the union wage demands

5. The structural model of the labor market that is used by Pencavel and Hartsog was developed to test for the wage and employment effects of unions without assuming that employment is unilaterally set by employers, or that the union wage premium is exogenous. It should also be noted that their model also differs from that estimated by Lewis (1964). They use only the percent organized variable to capture the effect of unionism and not the estimated union wage premium. 
by substituting for higher quality labor then "quality adjusted" wages will not rise as much as measured wages." Since firms might reduce their demand for unskilled workers relative to skilled workers, the effect on total demand may differ from that on a particular type of labor.'

Kahn (1978), Kahn and Morimune (1979), and Holzer (1982) provide cross-section estimates of the effects of variations in the extent of union membership across SMSAS on employment, hours worked, and unemployment stability. These cross-section studies use the fraction of employed workers in an SMSA who are union members as their measure of union strength, because it is felt that unionism will affect all workers in the same labor market and not just those in the same industry. That is, workers who may be displaced, because of union wage demands are likely to seek employment not just in that industry, but throughout the local labor market. By using detailed cross-section data either from the Current Population Survey (CPS) or the Survey of Economic Opportunity (SEO), these studies are better able to control for individual characteristics and labor market variables that affect employment. These cross-section studies seem preferable to the aggregate time series analyses, because they avoid some of the aggregation problems that emerge in the time series studies. However, like the time series studies mentioned above, the cross-section studies do not address the issue of

6. The potential importance of these biases can be seen by the fact that the estimates of the quality-adjusted union relative wage effect differ from those derived in cross-section studies. See Parsley (1980).

7. See Pencavel and Hartsog $(1984$, p. 216) for further discussion of these limitations. 
unionism occurs primarily through increased unemployment or reduced labor force size.

In any case, the results of these studies are again somewhat inconclusive. Kahn (1978) finds that annual hours worked are significantly reduced for non-union females but not for non-union males. These effects did not differ by race. Holzer (1982) however consistently finds a negative employment effect for young white males, but not for older white males and black males. His results are sensitive to the sample year and the specification of the estimated equation. The difference in these results could be due to differences in sample years, or to the fact that Kahn (1978) examines annual hours worked. while Holzer (1982) looks at employment level\$. Given this, it might be useful to examine in greater detail whether the disemployment effect of unionism occurs primarily through employment levels or through the number of hours worked for those who remain employed. Further, since Pencavel and Hartsog (1984) also found that the employment effect of unionism varies across time. it would seem that an analysis using recent data would be valuable.

\section{I Theory}

In this section, we discuss the effect of unions on the number of workers who are employed, unemployed, and in the labor force. Much of the theory used in this section was developed previously in the minimum wage literature by Welch (1974), Gramlich (1976), and Mincer (1976). The models 
developed by these authors provide a useful framework for analyzing the employment and unemployment consequences of the imposition of a union wage rate that is above the market clearing value. The simple one-sector neoclassical model yields fairly straightforward predictions about the effects of unionism. As seen in figure 1 , if unions increase wages above the competitive wage level, $W_{0}$, to $W_{1}$, employment (or hours worked) will fall from $\varepsilon_{1}$ to $E_{1}$, . The reduction in employment in this simple model results from profit-maximizing firms moving up their labor demand curves in response to union wage demands. ${ }^{3}$

8. It should be noted that this result relies on the assumption that in the face of union wage demands, employers remain on their labor demand curves when setting employment. Although this assumption or model of employment determination is in widespread use, recent work by Barro (1977) and Pencavel and Hartsog (1984) has called into question its validity. An employment rule that allows firms to set employment after the wage is given has been shown to leave mutually beneficial trades unexploited and involve a solution that leaves workers and firms off the contract curve. An optimal employment rule would involve the joint determination of employment and wages by labor and management. Under such a rule, movements in union wages need not be associated with movements along the labor demand curve and resultant reductions in employment. However, since observed union contracts leave the employment decision to management, we assume that employment is determined unilaterally without attempting to explain why contracts take this form. 
With a fixed 'labor force, or inelastically supplied labor, this reduction in employment translates into an equal increase in the level of involuntary unemployment. I $n$ this case $E,-E_{11}$ workers would like to work, but are unable to gain employment at the new union wage rate. Thus, in the context of a simple one-sector model with a fixed labor force, the employment and unemployment effects of unions are of equal magnitude. If labor is elastically supplied however, the effect on measured unemployment of an increase in union wages is ambiguous. In this case, $E,-E_{1}$, workers want employment, but cannot get it at the union wage (see figure 1). These workers will show up as unemployed only if they continue to engage in search for the rationed E. jobs. As Welch (1974) pointed out, the determination of how many, if any, of them will remain in the labor force requires a model of probabilistic search behavior. Consequently, this simple model yields ambiguous predictions about the effect of unions on the measured unemployment, but predict unambiguously that employment will fall.

A fundamental problem with this simple one-sector analysis is that it does not allow for the possibility that there are non-union workers in the economy. Consequently, this simple model may be useful in analyzing the employment effects of unions within a firm, but will be of limited value in studying the industry-wide or aggregate consequences. Multi-sector models that allow for the presence of a non-union sector have been developed by Johnson and Mieszkowski (1970) and Diewert (1974). These general equilibrium models examine the impact of unions on non-union wages in a world with varying factor intensities. Within the minimum wage literature, Welch (1974), Mincer 
(1976), and Gramlich (1976) have also developed multi-sector models to study the employment and unemployment effects of legislated wage floors, but they have typically assumed that factor intensities do not vary across sectors. In a multi-sector model, an increase in wages in the union sector again leads to a reduction in employment in the unionized sector. as employers move up their labor demand schedules. The higher wage, $\boldsymbol{W}_{1}$, creates an excess supply of workers who are now willing to work in the non-union sector if the non-union wage is also w.,. The addition of these workers to the non-union sector shifts out the supply cur-ve in that sector.' This increase in the supply of labor in the non-union sector will alter either wages or employment in the non-union sector, and most likely both."' '

9. Gramlich (1976) has noted that if union jobs go to workers with the lowest reservation wage, then the supply curve for workers in the non-union sector would shift out only in that region above the reservation wages of the displaced workers. If jobs are assigned randomly then a parallel shift in the labor supply curve will occur.

10. Mincer's (1976) analysis implies that the existence of a union premium may cause some worker's to prefer being unemployed, but in the queue for union jobs to being employed in the non-union sector. Consequently, a union wage premium may cause labor to flow from the non-union to union sector. He has shown that a net flow of labor from the union to non-union sector occurs if the elasticity of demand for labor exceeds the turnover rate in the union sector. As noted by Holzer (1982), given the low turnover rates in the unionized-sector, this condition will in general be met. 
The effect on total employment, $D_{1}$, depends upon the impact of unions on average wages in the economy.

(1) $\frac{\partial D_{1}}{D_{1}}=n \dot{w}$

where $\dot{w}=$ the percentage change in average wages.

$n=$ the elasticity of labor demand.

The change in average wages is a weighted average of the percentage change in wages in the union and non-union sectors.

(2) $\dot{w}=k \dot{w}_{11}+(1-k) \dot{w}_{n}$,

where $\quad k=$ percent of employment that is unionized

$$
\dot{w}_{1}=\text { percentage change in wages in sector } i \text {. }
$$

From (2) we can see that the effect on aggregate employment of an increase in union wages (or in the percent of the workforce that is organized) will depend on the impact of such a change on non-union wages. Average wages, and hence employment, w ill change as long as:

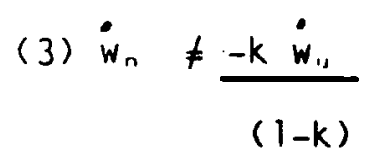

Welch (1974) has shown that in a two-sector model with constant intensities, the changes in non-union wages will be a function of the elasticity of labor supply, $\boldsymbol{\varepsilon}$ the percent unionized, $\mathbf{k}$, and the change in 
union wages, $W_{11} \cdot 1$ Thus we have:

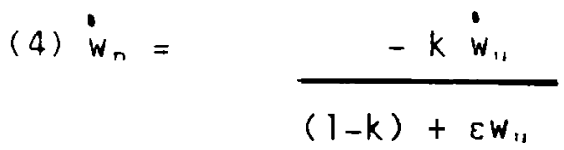

From (4) we see that unless the elasticity of labor susoly is zero $(\varepsilon=0)$, non-union wages will not fall enough to prevent average wages from rising and total employment from falling. Falling wages in the non-union sector cause workers with high reservation wages to withdraw from the labor force, thus causing total employment to decline." Using (2) and (4) we can express the elasticity of total employment with respect to union wage changes as:

(5) $\frac{\partial D_{1}}{\partial W_{11}}=\frac{k, W_{1 .}}{(1-k)+\varepsilon W_{11}}$

The higher the elasticity of supply, $\varepsilon$, or the greater the percent organized, $k$, the greater the disemployment effect associated with an increase in union wages. However, if labor supply is inelastic, total employment will remain fixed. $\cdots$

11. See Welch (1974, p. 304, equation 6). The change in non-union wages is not a function of the elasticity of labor demand in this model because of his assumption that the elasticity is constant across sectors. Thus, while a high elasticity of demand leads to a bigger disemployment effect in the union sector, it also means that more workers will gain non-union employment as wages fall.

12 It is possible that the existence of a union wage premium may actually draw more workers into the labor force than cause them to exit because of the depressed non-union wage rate. This will occur, however only if the turnover rate exceeds the elasticity of demand for labor. As noted earlier, this condition is unlikely to hold in the union sector. 
In a general equilibrium model with variable factor intensities. the effect of unions on wages in the non-union sector and hence on total employment. is ambiguous. If the unionized sector is the labor-intensive sector then, as shown in Johnson and Mieszkowski (1970), both the substitution and the scale effect will result in a reduced capital/labor ratio in the non-union sector, and hence a reduction in the marginal product of labor and wages. However, with a capital-intensive unionized sector. non-union workers will get higher wages if the scale effect is greater than the substitution effect and lower wages if the converse is true. In either case. increases in union wages or in the percent of the labor force that is unionized will tend to be associated with an increase in average wages and a fall in total employment, as long jas labor supply is not completely inelastic.

Work by Mincer (1976) has suggested that a growing union wage differential may also generate "permanent" or "equilibrium unemployment." because wages will not fall to the level to equilibrate the supply and demand for labor in the non-union sector. Wages will remain above this equilibrium level because some workers who do not have union sector jobs may prefer to remain unemployed until one of these jobs opens up. The existence of workers who prefer to search rather than accept employment in the non-union sector leads to 
voluntary, or search, unemployment similar to the official definition of unemployment. ':

In the long run, the movement of workers across sectors will lead to an equilibration of the expected utility of the wages in the two sectors. That is, the expected utility of a relatively more certain non-union job will equal the expected utility of a more uncertain but higher-paying union job; for risk-neutral workers, the expected value of wages in the two sectors will be equal." Thus, we have

(6) $\mathrm{PW}_{1,}=\mathrm{W}_{\mathrm{n}}$

where

$P$ is the probability of being employed in the union sector, and $W$, and W. are wages in the union and non-union sector, respectively. "

(7) $z=W_{11}-W_{n}=1-P$

W. $\quad P$

13. It should be noted that this model makes the strong assumption that workers can not engage in search while employed in the non-union sector. The Gramlich-Mincer model can be modified, however, to incorporate search while employed without any changes in the qualitative nature of its predictions. See Brown, Gilroy and Kohen (1982) for a discussion of this issue.

14. Gramlich (1976) allows for the existence of transfers like unemployment insurance. This raises the expected value of unionsector compensation, but does not alter the qualitative nature of our results.

15. Following Mincer (1976), we are assuming that the probability of getting employment in the non-union sector is 1 . 
The probability of being employed in the union sector depends on the number of vacancies in the covered sector relative to the number of job seekers. If employment in the union sector equals $D_{1}$, and the turnover or vacancy rate is 6 , then the probability of finding a job in the union sector is:

$$
P=\frac{\delta D_{u}}{U+\delta D_{u},}
$$

where $U$ is the number of unemployed job seekers. As shown in Mincer (1976), the voluntary unemployment rate can be expressed as a function of the unfon wage effect, the percent organized, and the turnover rate:

(9) $U_{A}=$

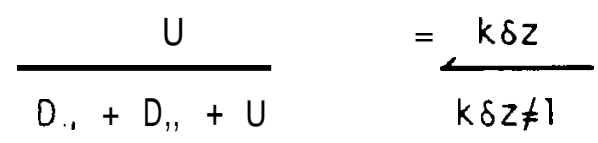

From (9) we can see that increases in the percent organized or the union wage premium will lead to an increase in unemployment relative to employment. ${ }^{\prime \circ}$

16. This assumes that changes in union coverage have no effect on the union/non-union wage differential. Although there is currently debate over whether changes in coverage may increase the union wage of premium, there is no evidence to suggest that it decreases it. Thus. the qualitative nature of'these predictions is unlikely to be altered by relaxing this assumption. 
Or:

(10) $\frac{\partial U_{\Delta}}{\partial k}=\frac{6 z>0}{[k \delta z+1]^{\prime}}, \frac{\partial U_{A}}{\partial z}=\frac{\delta k}{[k \delta z+1]^{2}}>0$

Intuitively, as unions increase their wage demands, employers move further up their demand curves, thus restricting employment in the covered sector. This displacement of workers from the unionized sector leads to an increase in the supply of non-union workers. a rise in unemployment, or both. Unemployment rises because some workers opt to search for a union job rather than accept employment at a non-union job for a lower wage. Unless the elasticity of labor supply in the non-union sector is zero. the increas'ed supply of workers to the non-union sector will also result in some labor force withdrawals." Increases in the extent of coverage has a similar effect on employment and unemployment because it involves an increase in the effective cost of labor in the union sector.

\section{Empirical Results}

To test for the employment and unemployment effects of unions, we used data from the 1983 Current Population Survey (CPS) Earnings File and Census data on SMSA characteristics. This data set was chosen. in part, because it contains detailed personal characteristics for each respondent that allow us

17. Labor flows in this direction as long as the turnover rate is lower than the elasticity of demand for labor in the union sector. Given the low turnover rates in unionized jobs, we might expect that in general this condition will hold. 
to control for d'ifferences in worker quality. In addition, it contains earnings and union membership data across individuals in each SMSA. To insure a sufficient sample size in each of the 44 SMSAs in our sample we combined the survey responses for each month over the year, which yielded 104,409 observations. 18

To examine the disemployment effect of unions, we initially looked at the effect of unionism on the probability of someone in the population being employed. Because displaced workers from the unionized sector may become either unemployed or withdraw from the labor force, the employment and unemployment effects of unionism need not be the same. Since the distinction between unemployed and not-in-the labor force may not be that strong, and some of those displaced by unions may withdraw from the labor force. the probability of being employed may be a better measure of the "true" disemployment effect of unionism than the probability of being counted as unemployed. An additional benefit from focusing on employment status is that we can examine whether unionism has different effects on the likelihood of gaining part-time versus full-time employment. These effects may differ substantially if unionism affects the length of the workweek for those who remain employed.

18. Beginning in 1981, the CPS reduced the number of surveyed individuals and asked detailed employment questions of only one-quarter of the sample each month. As a result, the number of union members in many of the SMSAs in any given month is too small to allow us to have sufficient degrees of freedom for estimation. 
As shown in section II, the effect of unionism on employment and unemployment is a function of both the percent organized and the union wage premium. Consequently, as suggested by equations (5) and (9), the measure of the effect of unionism that we used is the product of the percent of employment in an SMSA that is unionized and the union/non-union wage differential.'.' This index is similar to the Kaitz index, widely used in the minimum wage literature for examining potential disemployment effects of a legislated wage increase above competizive levels."

Previous cross-section work by Holzer (1982), Kahn and Morimune (1979), and Kahn (1978) has implicitly constrained the effect of unions on employment to operate solely through differences in the percent organized across SMSAS. This constraint is analogous to requiring that the union relative wage effect? be the same across SMSAs, which might be inappropriate for theoretical and econometric reasons.

19. We restrict our sample to the nonfarm economy when we are calculating both the union wage premium and the percent of employed that are union members. The sample was restricted to civilians age 16-65 working for wages and salary.

20. In minimum wage studies, Ehrenberg (1980) and Welch (1978) have suggested that this type of index implicitly constrains the percent covered and wage premium to have symmetric effects on employment or unemployment. They have suggested several alternative measures that allow for different effects from the percent covered and the wage premium. As a check on the sensitivity of our results to this restriction, we estimated our employment equations with indexes that rise more than proportionately with changes in the percent unionized or with the union wage premium. The qualitative nature of our results were not sensitive to the use of these other indexes. 
Recent theoretical work by Lazear (1983) suggests that the percent unionized in an industry or region is not a good measure of union power. He shows that to the degree the cost of running a union differs across industries, different wagelemployment packages will be negotiated by unions facing the. same opportunity locus or having the same strength. That is, unions in industries where costs are high will tend to prefer higherwagellower-employment share packages than will unions in relatively low-cost markets. Consequently, the per-cent of employment that is unionized or the union wage premium will vary across industries or regions, even though union power is the same. Greater union strength will be indicated by a better wagelemployment share package and not just a higher percent unionized. Consequently. it is necessary to control for both the wage premium and the? percent unionized in order to get a measure of union strength across markets. To the degree the union relative wage effect differs across SMSAs, failure to control for differences in the wage premium will yield inefficient and potentially biased estimates. Since the union wage premium may be determined by many of the same exogenous variables that determine employment, this term is likely to be correlated with the independent variables in the model. The result might be that the estimated coefficients in previous studies are biased.

To construct our measure of union strength, it was first necessary to derive an estimate of the union/non-union wage differential in each SMSA. To do this, we estimated separate wage equations for union and non-union members 
in each SMSA

(11) $\ln W_{1}=B X_{1}+e \ldots$

where $W_{1}$, is average hourly earnings of individual, i, in SMSA, $k, X$, is a vector of individual characteristics that determine wages; and e, is an error term. In estimating these wage equations, we included controls for schooling. experience, experience squared, occupation, industry, race, gender-, full-time, veterans, and marital status.' From (11) the union/non-union wage differential for each SMSA, $z$,, was calculated as:

(12) $Z_{1}=\exp \left\{\left(\beta_{1},-\beta_{n}\right) \bar{X}\right\}-1$

where $\beta$ represents the estimated coefficients from the union or non-union wage regression, and $\bar{X}$ is the mean value of the individual characteristics in each SMSA.

This procedure treats union status as exogenous when estimating the union wage premium. Work by Heckman (1978) and Duncan and Leigh (1985) and others suggests that this may yield biased estimates of the "true" union wage effect, because it ignores the selectivity problem associated with the joint determination of union membership and the union wage premium. Work by Freeman

21. Since the respondents were asked only asked their union status, and the earnings questions in the last month of their rotation in the CPS sample, we also included monthly dummies to control. for seasonal variations. 
and Medoff (1981.) and Freeman (1984) however, suggests that current

econometric techniques for addressing this problem suffer from extreme sensitivity to changes in sample period or model specification. Consequently, they have argued against using such corrections as the inverse of the Mills ratio in estimating this differential, and instead, advocate using ordinary least squares (OLS) estimates, which do not appear to suffer from these problems. Because we are only interested in the effect of variations in the size of this premium on employment and not in its level per se, we have chosen to use the estimates from these OLS regressions. Although selectivity bias may mean that the estimated wage differentials are biased upwards, it is not clear why the selectivity bias should vary across SMSAs in a way that is correlated with the error term in our employment equation. In the absence of this kind of correlation, the employment equations should still yield unbiased estimates of the effect of union strength on employment and unemployment.

In examining potential disemployment effects of unions, we attempted to control for other factors besides unionism that may shift either the supply or demand for labor and hence affect the likelihood that an individual will be employed. Included in the model is a vector of individual characteristics that may affect either the supply or demand for labor as well as SMSA specific characteristics that reflect local labor market conditions. In particular, we control for differences in schooling. potential labor market experience, race, gender, marital status, geographic region, size of SMSA, local unemployment rate, and the percent of the population in an SMSA that receives Aid to Families with Dependent Children (AFDC). ¿2

22. We also included monthly dummies to control for seasonal variations in employment. 
The resulting employment equation is:

(11) $E_{1}=B_{2} Z_{1}+\delta U N_{2}+e_{1}$.

where $E$, is an index that indicates the employment status of the ith individual in the kth SMSA. $Z$, , is a vector of personal and SMSA-specific characteristics that affect that probability of being employed, and UN, is the measure of union strength.

The results of estimating these linear probability employment equations for the employed workers and for part-time and full-time employed workers separately are presented in table 1.': The signs of the variables that control for local labor market conditons and individual characteristics are generally consistent with theoretical predictions. Increases in human capital (schooling and experience) and local demand (lower unemployment) lead to increases in the likelihood that an individual will be employed. Conversely, increases in the fraction of the population receiving AFDC has a negative. albeit insignificant, effect on the likelihood of being employed. As seen in regression (1), increases in union strength have a negative and significant impact on the probability of being employed. Thus, the fraction of the

23. There are several well-known problems with the linear probability model, having to do with heteroscadasticity and prediction that lie outside the $0-1$ interval. Because of the cost of estimating logit equations with a data set this large, however, we have not attempted to estimate this model using maximum likelihood techniques. Nonetheless, the estimates from the linear probability model should be consistent. 


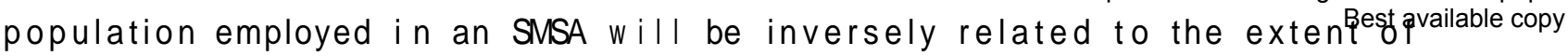
unionism and the union wage premium. The magnitude of this effect can be captured by calculating the change in the probability of being employed for a base case or average worker. when the value of the union strength variable changes by one standard deviation from its mean value:" The expected probability of being employed was found to decline from 0.829 to 0.825 with this increase in union strength. Alternatively. the probability of being employed for our average worker in the SMSA where union strength is highest (San Bernardino, CA.) is only about 2 percent less than if that worker lived in the SMSA where union strength is the least (Atlanta, GA.). ' Thus, it would appear that changes in the extent of union strength have only a very limited impact on aggregate employment. Changes in schooling, experience, or local labor. market conditions have a much greater impact on the likelihood of being employed than unionism. For instance, a standard deviation increase in the number of years of schooling increases the likelihood of being employed for the base case worker about 10.6 percent, while a standard deviation increase in the number of years of potential labor market

24. The base case worker is a single white male with 12.6 years of schooling, 18.5 years of experience who lives in the East-North-Central region of the United States in an SMSA with an unemployment rate of 9.4 percent in March. a population of 3,479,000, where 5.5 percent of the population receives AFDC, and the union strength variable equals 0.031

25. The union strength variable ranges from 0.0795 to -0.0015 . In San Bernardino, the probability of being employed is 0.818 while it is 0.836 in Atlanta. 
experience increases it by 36.6 percent:

From regressions (2) and ( 3 ). we see that unionism will affect the length of the workweek for those who remain employed. If unionism has no effect on hours worked, then the effect on the probability of working full-time should be the same as it is on the likelihood of working part-time. Conversely, if employers reduce the hours worked of those that they keep employed, then our union variable should be positive in the part-time regression and negative in the full-time regression. We found that this is indeed the case. The union variable was negative and significant in the full-time employment equation, while it was positive but insignificant in the part-time employment equation. Using these estimated coefficients, we can see? that a standard deviation increase in union strength leads to a 0.7 percent reduction in the probability of being employed full-time and a 1.0 percent increase in the probability of being employed part-time. "' In addition, both the point estimate and the degree of significance of the union strength variable are much higher in the full-time equation than in the total employment equation. These results suggest that part of the disemployment effect of unions comes through reducing the number of hours worked on that job.

26. The standard deviation for schooling is 2.9 years and 14.4 years for experience.

27. The probability of being employed full-time and part-time for our base case workers is 0.677 and 0.152 , respectively. 
As a further test of this hypothesis, we reestimated the employment equation with the dependent variable as the probability of working part-time given that the individual was employed. Unions may reduce the workweek by increasing the relative frequency of part-time jobs relative to full-time jobs. As seen in regression (4) in table 1, increases in union strength increase the fraction of employment that is part-time. A standard deviation increase in union strength increases the likelihood of working part-time for the base case worker by about 3 percent.'" Given these estimates, the average worker is about 19 percent less likely to be working full-time in the highest union strength SMSA than he is in the lowest union strength SMSA. Thus. these estimates suggest that increases in union wages or the percent organized might have a bigger effect on hours worked per week or the mix of: full-time and part-time jobs than on the level of total employment.

In section III, it was shown that the disemployment effect of unions was a function of the elasticity of labor supply. The greater the elasticity of supply, the greater the disemployment effect. Given this, we might expect that the disemployment effect would be largest for groups with a weak labor force

28. The probability of working part-time for the base case worker is 0.1429. The base case worker in this sample is again a single white male with 13.2 years of schooling, 17.8 years of experience who lives in the East-North-Central region of the United States in an SMSA with an unemployment rate of 9.2 percent in March. a population of $3,391,600$, where 5.5 percent of the population received AFDC, and the union strength variable equals 0.031 . 
attachment or a high elasticity of labor supply. Teenagers or young people may be more adversely affected than older- workers, while females may suffer more than males. To test for differences in the disemployment effect across groups, we estimated separate employment equations for part-time and full-time workers by gender and age group. These results are presented in tables 2 and 3 .

The basic predictions of our theory seem to hold. Based on the point estimates from these regressions, we see that the disemployment effect of unions is smaller for prime age males than for- teenagers or 20-24 year old males. In fact, prime age males do not appear to be adversely affected by changes in union strength at all. This probably reflects their strong labor force attachment or low elasticity of labor supply. Interestingly, the evidence does not support the hypothesis that teenagers are more adversely affected than 20-24 year olds. As expected, the disemployment effect of unionism is greater for prime age females than for prime age males: '' In general, increases in the union wage premium or the percent organized also affect the workweek or the likelihood of being employed part-time more for females than for males.

To investigate whether the disemployment effect of union works primarily through increasing unemployment or decreasing labor force participation, we also estimated an equation where the dependent variable is the likelihood of being in the labor force. If unionism primarily reduces the size of the labor

29. The adverse effect of unionism increases with age for females. Whether this reflects a greater attachment to the labor force is a question for further research. 
force, then the coefficient on the union strength variable in the labor force regression should equal that in the employment regression. The results from estimating the labor force participation equation are presented in regression (5) in table 1.

The union coefficient is both negative and significant in this regression. The point estimate on this term is about 25 percent bigger than it is in the employment equation. This suggests that increases in union strength cause both an increase in the number of unemployed workers and a reduction in labor force participation. When these equations were estimated for different gender and age groups. we found that, in general. females suffered a bigger labor force effect than males. This was particularly true when comparing prime age males and females. ${ }^{30}$ Based on the regressions in table 1 , however, it would appear that the disemployment effect of unionism results primarily from a reduction in the size of the labor force and not from an increase in the number of unemployed. Thus, unemployment rates will tend to be higher in regions with a high degree of union strength, primarily because of a reduction in the size of the labor force, and not because of an increase in the number of unemployed. It should be noted, however, that the magnitude of the effect of changes in union strength on the labor force is quite small. A standard deviation increase in union strength reduces the likelihood of being in the labor force by only 0.1 percent." Our average or base case worker is about 3 percent less likely to be in the labor force if he resides in the

30. These results are available from the author upon request.

31. The likelihood of being in the labor force for our base case worker is 0.895 . 
highest union strength SMSA than if he resides in the lowest union strength SMSA.

\section{$\underline{\text { V. Conclusions }}$}

In this paper, we present estimates of the effect of changes in union strength on the likelihood of being employed or in the labor force. The results of this paper suggest that in areas where the percent of the labor force that is unionized is high or where the union/non-union wage premium is large; workers are less likely to be employed or in the labor force and more likely to be unemployed. Besides altering the number of workers employed or in the labor force, unions reduce the likelihood of having a full-time job by altering the mix of part-time and full-time jobs in the economy. Thus, unions appear to adversely affect the average workweek for those who remained employed. These disemployment effects from unions were concentrated mainly among females and young men. with little if any negative impact on prime age males. These disemployment effects, however, were in general found to be quite small. with unionism having a more pronounced effect on the mix of part-time and full-time employment, and hence the workweek, than on the number of jobs. All of these effects were dwarfed in importance by the state of the local labor market and the level of an individual's human capital or skills.

32. The probability of being in the labor force for the base case worker is 0.881 in San Bernardino and 0.908 in Atlanta. 


\section{Data Appendix}

The data for this study come from the Current Population Survey 1983 and from the Bureau of Census, County and City Data Book. 1982.

UN is the product of the percent unionized and the union wage premium in each SMSA.

Unemployment Rate is the local unemployment rate for all workers in the SMSA.

Population is the number of people living in the SMSA.

AFDC is the proportion of the population in the SMSA receiving AFDC payments.

Schooling is the number of years of schooling completed by the individual.

Experience is calculated as Age -Schooling - 6

Race is a dummy that equals 1 if the individual is white.

Sex is a dummy that equals 1 is the individual is a male.

In addition to these variables, each regression contains a dummy term that equals 1 if the individual is married, nine regional dummies where the omitted category is the East-North-Central region, and 11 monthly dummies to control for the month the individual was surveyed. The complete regression results are available from the author upon request. 
Figure 1 Employment Effects of Unions

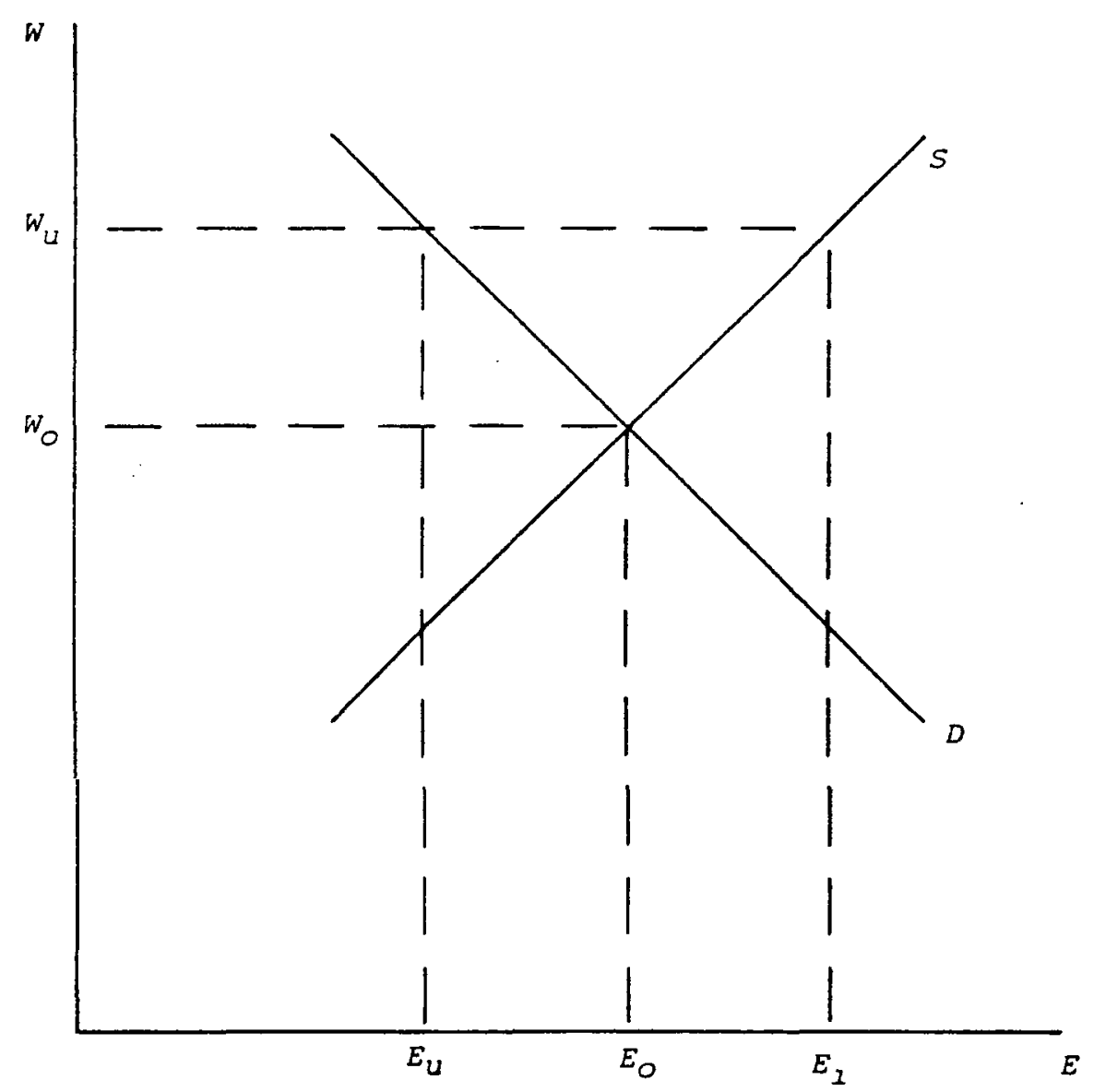




\section{Dea Appendix}

The data for this study come from the Current Population Survey 1983 and from the Bureau of Census, County and City Data Book. 1982.

UN is the product of the percent unionized and the union wage premium in each SMSA.

Unemployment Rate is the local unemployment rate for all workers in the SMSA.

Population is the number of people living in the SMSA

AFDC is the proportion of the population in the SMSA receiving AFDC payments .

Schooling is the number of years of schooling completed by the individual.

Experience is calculated as Age -Schooling - 6 .

Race is a dummy that equals 1 if the individual is white.

Sex is a dummy that equals 1 is the individual is a male.

In addition to these variables, each regression contains a dummy term that equals 1 if the individual is married, nine regional dummies where the omitted category is the East-North-Central region, and 11 monthly dummies to control for the month the individual was surveyed. The complete regression results are available from the author upon request. 
Table 1: Effects of Unions on Employment and Labor Force Status

Variables

Constant
(3)

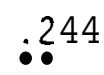

$(26.2)$

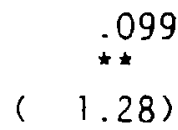

$(-2.22)(-3.07)$
(9.75) (-9.28)

$$
-.234
$$

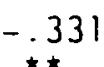

(4)

(5)

Unemployment

rate

$$
\begin{array}{cc}
-* 974 & -1.01 \\
(-13.9) & (14.0)
\end{array}
$$

Population
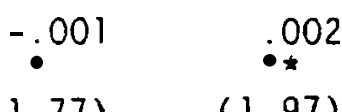

$$
(-1.77)
$$

(1.97)

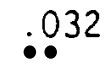

$(.06)$

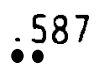

.319

(43.4)

(27.2)

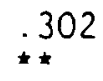

$-.292$

(2.74)

(2.97)

AFDC

$$
-1.38
$$

$-.005$

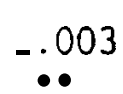

$(-5.16)$
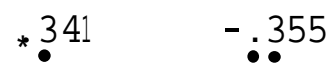

$$
(-1.33)
$$

$$
(-.05)
$$

$$
-.133
$$

(4. 60$)$

$(-5.14)$

School ing

$$
\begin{array}{cc}
: 030 & : 031 \\
(60.5) & (61.3)
\end{array}
$$$$
(-1.73)
$$
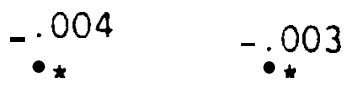

$(-3.23)$

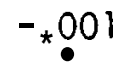

$(-4.49)$

Experience

$$
\because 021
$$

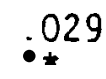

$(-3.63)$

$-.146$

$-: 341$

$(-1.34)$

$(-3.52)$

$(58.6)(78.8)$

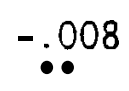

$(-30.6)$

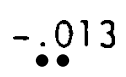

.023

$$
-.0005 \quad-.0006
$$

Experience
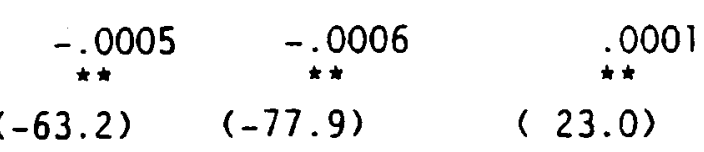

$(-24.9)$

$(49.1)$

$$
(-63.2) \quad(-77.9)
$$

$(23.0)$

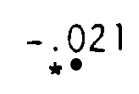

.021

Sex
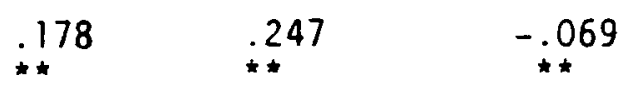

$(-52.1)$

$(61.1)$

$(65.5)(88.3)$

$(-34.5)$

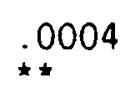

$-.0005$

$(44.6)$

$(-71.0)$

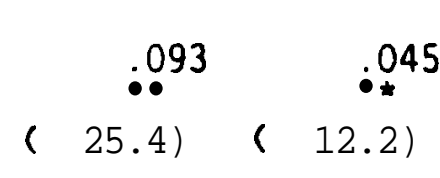

Race
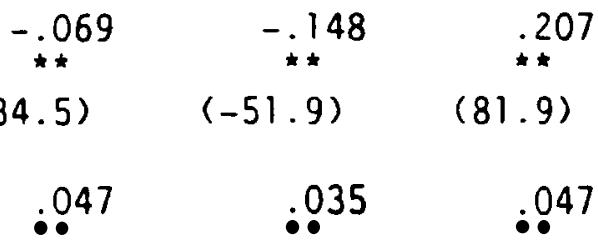

$(-51.9)$

(81.9)

$R^{2}$

.147

.035
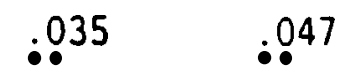

$8.72)$

$(13.8)$

.102

.160

Notes: See data Appendix for a description of the independent variables. - significant at 0.10 level.

* signficiant at 0.05 level. 
Table 2: Effects of Unions on Full-Time Employment by Age and Gender

\section{Males}

Variables

Constant

UN$$
16-19
$$$$
-.939
$$$$
(-16.0)
$$$$
-.675
$$

(1.92)

$-.524$

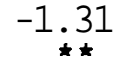

$(-4.53)$

$-.844$

$(-1.85)$

20-24

$-.236$

$(2.87)$

$(20.1)$

.408

25-65

$(16.1)$

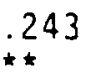

(1.55)

Unemployment

$$
\text { rate }
$$$$
(-2.19)
$$$$
-.005
$$

(.74)

$-.392$

$(-.89)$

(1.91) .089

(21.5)

(7.52)

$(19.0)$

(14.5)

.106

Experience

$$
-.001
$$

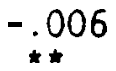

$(-1.40) \quad(-13.2)$

(14.2)

$$
\text { (8.22) }
$$

.142$$
.003
$$
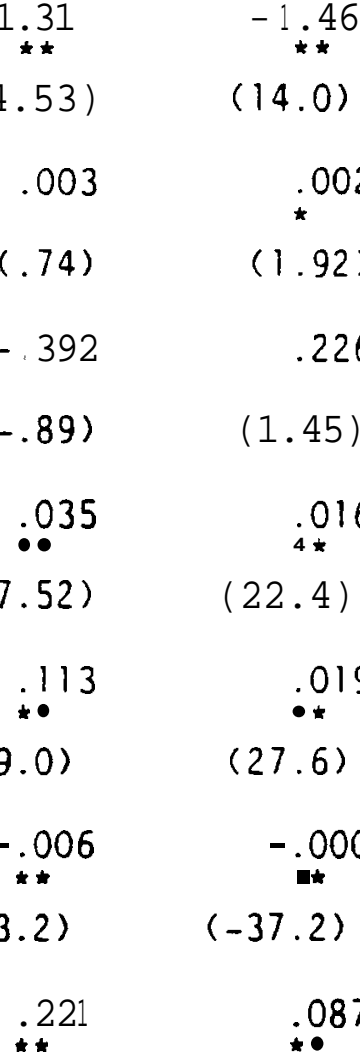

$(14.0)$

.002

(1.92)

.226

(1. 45)

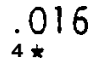

$(22.4)$

.019

$(27.6)$

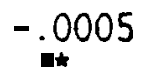

$(-37.2)$

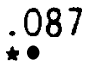

(15.3)

.144

.136
$R^{\prime}$

.111
16-19

$-.885$

Females

$\begin{array}{ccc}-1.09 & -.434 & .697 \\ \$ \neq & \$ & \$ \\ (-.33) & (-1.01) & (-3.89)\end{array}$

$-.812$

$(-6.84)$

$(.13) \quad(-4.20) \quad(-6.84)$

$.004 \quad .005$

.001

$(.69)$
(1.51)
(1.31)

$-.463$

$-.586$

$-.244$

$(1.44) \quad(-1.37) \quad(-1.38)$

.081

.068

.026

$(20.8)$

$(15.0)$

$(29.8)$
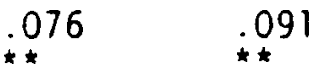

$(10.3)$

(15.5)

$(9.00)$

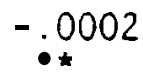

(9.05)

$(9.00)$

$(-1.24)$

.088

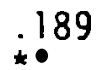

$-.019$

(8.18)

(12.9)

$(-3.04)$

.079

.108

Notes: See data appendix for a description of the independent variables. - significant at 0.10 level.

* significant at 0.05 level 
Table 3: Effect of Unions on Part-Time Employment by Age and Gender

Males

Variables

Constant

UN

UN
Unemployment
rate

16-19

20-24

(2.38)

(7.26)

.227

(.65)

$(.53)$

(.65)

$-.113$

$25-65$

$16-19$

: 106

(9.14)

.108

(1. 42)

$-.125$

$(-1.39)$

$-1.09$

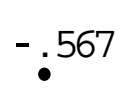

$(-1.85)$

$(-.51)$

$-.004$

$-.004$

$(-1.19)$

$(-1.27)$

$-.857$

$-.084$

$(-.25)$

$$
(-1.94)
$$

*014

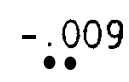

(2.68)

$(-2.60)$

*231

(3.87)

$(-2.39)$

$-.0001$

$-.041$

$-.001$

$(-.13)$

$(-.01)$

(9.33)

Females

AFDC

School ing

Experience
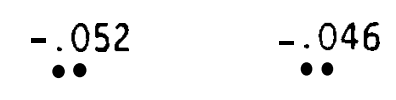

$(-5,56)$

$(-10.1)$

Experience

*004

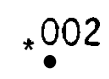

(4. 42)

(6.24)

$(-.10)$

$-.017$

$-.006$

$(-4.50)$

$(-2.02)$

$-.137$

.666

$-.332$

$(-1.54)$

(1.49)

$(-1.00)$

$(-.15)$
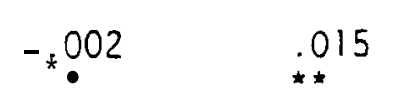

$-.019$

.004

$(-4.11)$

(2.79)

$(-5.39)$

$(5.91)$
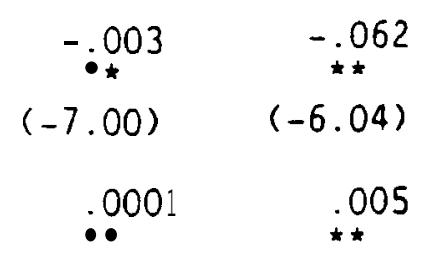

$-.066$

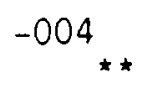

Race

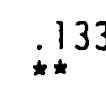

$-.004$

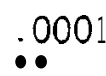

(6.97)

(3.75)

$(-14.3)$

$(6.57)$

(9.17)

$(-.38)$

.004

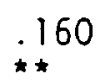

(1.16)

$(10.8)$

.010

.066

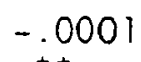

$R^{\prime}$

.047

.037

.057

(4.67)

$(7.13) \quad(-7.62)$

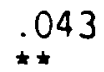

(9.80)

Notes: See data appendix for a description of the independent variables. * significant at 0.10 level. 
References

Earro, Robert J. "Long-term Contracting, Sticky Prices, and Monetary Policy." Journal of Monetary Economics, vol. 3, no. 3 (July 1977), pp. 305-16.

Brown, Charles, Curtis Gilroy, and Andrew Kohen. "The Effect of the Minimum Wage on Employment and Unemployment." Journal of Economic Literature, vol. 20, no. 2 (June 1982), pp. 487-528.

Diewert. W. E. "The Effects of Unionization on Wages and Employment: A General Equilibrium Analysis," Economic Inquiry, vol. 12, no. 3 (September 1974), pp. 319-39.

Duncan, Gregory M., and Duane Leigh. "The Endogeneity of Union Status: An Empirical Test," Journal of Labor Economics, vol. 3 (July 1985), pp. 385-402.

Ehrenberg, Ronald, and Alan Marcus. "Minimum Wage and Legislation and the Educational Outcomes of Youth," in Ronald Ehrenberg, ed. Research in Labor Economics, volume 3. Greenwich, CT: Jai Press, 1980.

Freeman, Richard. "Economic Determinants of Geographic and Individual Variation in the Labor Market Position of Young Persons," in Richard Freeman and David Wise, eds. The Youth Labor Market Problem: Its Nature, Causes, and Consequences. Chicago, IL: University of Chicago Press, 1982.

, and James Medoff. What do Unions Do? New York, NY: Basic Books, 1984.

Freeman, Richard. "Longitudinal Analyses of the Effects of Trade Unions," Journal of Labor Economics, vol. 2 (January 1984), pp. 1-26.

, and James Medoff. "The Impact of Collective Bargaining: Illusion or Reality," in Jack Stieber, Robert Mckersie, and D. Quinn Mills, eds.. U.S. Industrial Relations 1950-1980: A Critical Assessment. Madison. WI: Industrial Research Association, 1981.

Gramlich, Edward. "Impact of Minimum Wages on Other Wages. Employment, and Family Incomes," Brookings Papers on Economic Activity. 2, 1976 , pp. 409-51.

Heckman, James J. "Sample Selection as a Specification Error," Econometrica, vol. 47. no. 1 (January 1979), pp. 153-61.

"Dummy Endogenous Variables in a Simultaneous Equation System," Econometrica, vol. 46, no. 6 (July 1978), pp. 931-59.

Holzer. Harry J. "Unions and the Labor Market Status of White and Minority Youth," Industrial and Labor Relations Review, vol. 35, no. 3 (April 1982) pp. 392-405. 
Johnson. Harry G., and Peter Mieszkowski. "The Effects of Unionization on the Distribution of Income: A General Equilibrium Approach." Quarterly Journal of Economic Literature, vol. 84, no. 4 (November 1970), pp. 539-61.

Kahn, Lawrence. "Unions and the Employment Status of Nonunion Workers." Industrial Relations, vol. 17, no. 2 (May 1978), pp. 238-44.

, and Kimio Morimune. "Unions and Employment Stability: A Sequential Logit Approach," International Economic Review, vol. 20, no. 1 (February 1979), pp. 217-35.

Katz, Arnold. "Teenage Employment Effects of State Minimum Wages," Journal of Human Resources. vol. 8 (Spring 1973), pp. 251-56.

Lazear, Edward P. "A Competitive Theory of Monopoly Unionism," American Economic Review, vol. 83, no. 4 (September 1983), pp. 631-43.

Lee, Lung-Fei. "Unionism and Wage Rates: A Simultaneous Equations Model with Qualitative and Limited Dependent Variables," International Economic Review. vol. 19, no. 2 (June 1978), pp. 415-33.

Lewis, H. Gı-egg. Unionism and Relative Wages in the United States. Chicago, IL: University of Chicago Press, 1963.

"Efficiency in the Labor Markets' Relative Employment Effect of Unionism," American Economic Review: Papers and Proceedings, May 1964, pp. 123-32.

Mincer, Jacob. "Unemployment Effects of Minimum Wages," Journal of Political Economy Part 2, vol. 84, no. 4 (August 1976), pp. 87-104.

Murphy. Kevin. "Geographic Differences in U.S. Employment Rates: A Variance Decomposition Approach," Economic Inquiry, vol. 23, no. 1 (January 1985), pp. $135-58$.

Parsley, C.J. "Labor Unions' Effect on Wage Gains: A Survey of Recent Literature," Journal of Economic Literature, vol. 17, no. 1 (March 1980), pp. 1-31.

Pencavel, John, and Catherine Hartsog. "A Reconstruction of the Effects of Unionism on Relative Wages and Employment in the United States 1920-1980," Journal of Labor Economics. vol. 2 (April 1984), pp. 193-232.

Welch, Finis. Minimum Wages: Issues and Evidence. Washington. DC: American Enterprise Institute, 1978.

. "Minimum Wage Legislation in the United States," Economic Inquiry, vol. 12, no 3 (September 1974), pp. 285-318. 